\title{
Biomarkers on melanoma patient T Cells associated with ipilimumab treatment
}

\author{
Wenshi Wang ${ }^{1 *}$, Daohai Yu², Amod A Sarnaik', Bin Yu', Maclean Hall', Dawn Morelli', Yonghong Zhang ${ }^{3}$, \\ Xiuhua Zhao ${ }^{2}$ and Jeffrey $S$ Weber ${ }^{1}$
}

\begin{abstract}
Background: Ipilimumab induces long-lasting clinical responses in a minority of patients with metastatic melanoma. To better understand the mechanism(s) of action and to identify novel biomarkers associated with the clinical benefit and toxicity of ipilimumab, baseline characteristics and changes in $\mathrm{CD}^{+}$and $\mathrm{CD} 8^{+}$ $T$ cells from melanoma patients receiving ipilimumab were characterized by gene profiling and flow cytometry.

Methods: Microarray analysis of flow-cytometry purified $\mathrm{CD}^{+}$and $\mathrm{CD} 8^{+} \mathrm{T}$ cells was employed to assess gene profiling changes induced by ipilimumab. Selected molecules were further investigated by flow cytometry on pre, 3-month and 6-month post-treatment specimens.

Results: Ipilimumab up-regulated Ki67 and ICOS on $\mathrm{CD}^{+}$and $\mathrm{CD}^{+}$cells at both 3- and 6-month post ipilimumab $(p \leq 0.001)$, decreased CCR7 and CD25 on CD8 ${ }^{+}$at 3-month post ipilimumab $(p \leq 0.02)$, and increased Gata3 in CD4 and $\mathrm{CD}^{+}$cells at 6 -month post ipilimumab $(\mathrm{p} \leq 0.001)$. Increased EOMES ${ }^{+} \mathrm{CD} 8^{+}$, GranzymeB ${ }^{+} \mathrm{EOMES}^{+} \mathrm{CD}^{+}$and decreased Ki67 ${ }^{+} \mathrm{EOMES}^{+} \mathrm{CD} 4^{+} \mathrm{T}$ cells at 6 months were significantly associated with relapse (all $p \leq 0.03$ ). Decreased $\mathrm{Ki} 67^{+} \mathrm{CD} 8^{+} \mathrm{T}$ cells were significantly associated with the development of irAE $(p=0.02)$. At baseline, low Ki67 ${ }^{+} E O M E S^{+} C D 8^{+} T$ cells were associated with relapse $(p \leq 0.001)$, and low Ki67 ${ }^{+} \mathrm{EOMES}^{+} \mathrm{CD} 4^{+} \mathrm{T}$ cells were associated with irAE $(p \leq 0.008)$.

Conclusions: Up-regulation of proliferation and activation signals in $C D 4^{+}$and $C D 8^{+} T$ cells were pharmacodynamic markers for ipilimumab. Ki67 ${ }^{+} \mathrm{EOMES}^{+} \mathrm{CD} 8^{+}$and $\mathrm{Ki} 67^{+} \mathrm{EOMES}^{+} \mathrm{CD} 4^{+} \mathrm{T}$ cells at baseline merit further testing as biomarkers associated with outcome and irAEs, respectively.
\end{abstract}

Keywords: CTLA-4, Antibody, Biomarker, Melanoma

\section{Background}

T cells play a pivotal role in the development of immune tolerance to self, autoimmunity, and anti-tumor responses. Cytotoxic $\mathrm{T}$ Lymphocyte-Associated antigen 4 (CTLA-4) is a surface receptor on T lymphocytes that down-regulates pathways of T-cell activation [1], serving as an immune check point molecule. It is expressed intracellularly in resting $\mathrm{T}$ cells, and is transported to the $\mathrm{T}$ cell surface after activation of the $\mathrm{T}$ cell receptor (TCR). TCR engagement leads to tyrosine phosphorylation of CTLA-4 at position 164 (164Y) via the SRC kinase and releases it from AP50, resulting in its surface

\footnotetext{
* Correspondence: Wenshi.wang@moffitt.org

'Department of Cutaneous Oncology and the Donald A. Adam Comprehensive Melanoma Research Center, H. Lee Moffitt Cancer Center, Tampa, FL, USA

Full list of author information is available at the end of the article
}

expression within 48 hours of $\mathrm{T}$ cell activation, leading to $\mathrm{T}$ cell tolerance and anergy. CTLA-4 expression is associated with decreased proliferation with cell cycle arrest at the $\mathrm{G}_{1}-\mathrm{S}$ interface and diminished cytokine secretion [2,3]. It decreases cell proliferation through the inhibition of mitogen-activated (MAP) kinases but promotes $\mathrm{T}$ cell survival through the binding of phosphoinositol-3 kinase and activating protein kinase $\mathrm{B}(\mathrm{PKB} / \mathrm{AKT})$ resulting in $\mathrm{T}$ cell anergy and tolerance without the death of T cells [4]. CTLA-4 signals suppress both $\mathrm{CD}^{+}$and $\mathrm{CD} 8^{+} \mathrm{T}$ cell responses via a tyrosine-based inhibitory motif $[5,6]$.

CTLA-4 blockade has antitumor activity in mice, and important effects on the breaking of tolerance [6-10]. In experiments with B16 melanoma, a therapeutic effect induced by CTLA-4 blockade with a vaccine was

\section{Biomed Central}

(c) 2012 Wang et al.; licensee BioMed Central Ltd. This is an Open Access article distributed under the terms of the Creative Commons Attribution License (http://creativecommons.org/licenses/by/2.0), which permits unrestricted use, distribution, and reproduction in any medium, provided the original work is properly cited. 
associated with the development of autoimmune vitiligo, suggesting that expansion of $\mathrm{T}$ cells recognizing melanocyte lineage antigens was associated with its therapeutic effect. Several autoimmune diseases were associated with the single nucleotide polymorphisms in the CTLA-4 gene, including hypothyroidism and type 1 diabetes [11]. In CTLA-4 $\%$ knockout mice, expansion of lymphocytes with diffuse lymphadenopathy and lymphoid infiltration of different organs occurs, consistent with a generalized expansion of T cells [12]. Similarly, both preclinical and clinical data indicate that CTLA-4 blockade results in activation and expansion of the total $\mathrm{CD} 4^{+}$and $\mathrm{CD}^{+}$effector $\mathrm{T}$ cells [13], and the breaking of self-tolerance has been shown in patients, as evidenced by the occurrence of immune-related adverse events (irAEs) observed with two different CTLA-4 antibodies, ipilimumab (Bristol Myers Squibb, Princeton, NJ) [14] and tremelimumab (Pfizer, New York, NY) [15].

Ipilimumab is a fully human CTLA-4 blocking $\operatorname{IgG}_{1}$ monoclonal antibody which induces long-lasting clinical responses in a minority of patients with metastatic melanoma [16-21]. Ipilimumab with or without a gp100 peptide vaccine, compared with gp100 vaccine alone, improved overall survival (OS) in patients with previously treated metastatic melanoma [22]. Ipilimumab when combined with dacarbazine improved overall survival in previously untreated patients compared to dacarbazine alone [23]. These were the first randomized Phase III trials to demonstrate a significant survival impact for patients with metastatic melanoma, yet few studies have shed light on its anti-tumor mechanism, or documented pharmacodynamic (PD) markers of the impact of ipilimumab. An increase in the absolute lymphocyte count (ALC) after 2 or 3 doses of the drug at weeks 4 and 7 has been documented [24], and may correlate with an improved outcome; increased CD4 $4^{+}$ HLA-DR ${ }^{+} \mathrm{T}$ cells have been shown in several studies to occur after ipilimumab therapy $[25,26]$; in several small cohort studies of brief duration, ipilimumab treatment increased the frequency of $\mathrm{CD}^{+} \mathrm{ICOS}^{\mathrm{hi}} \mathrm{T}$ cells in tumors and in the circulation, and it also induced antibody reactivity against the cancer-testis antigen NY-ESO-1 $[27,28]$. CTLA-4 abrogating antibodies do not impact on vaccine-specific immune responses [29] and even when administered with a peptide vaccine, tumor antigenspecific responses were only modestly increased [29, 30]. Recall responses to viral and other antigens were not altered by ipilimumab. In patients receiving another CTLA-4 abrogating antibody, tremelimumab, the ratio of intratumoral $\mathrm{T}$ cells to FoxP3 positive $\mathrm{T}$ regulatory cells was increased after treatment only in regressing lesions [30], suggesting a therapeutic impact of CTLA-4 abrogation on $\mathrm{T}$ cells infiltrating the tumor. The same investigators also demonstrated that peripheral blood Th17 cells were induced by tremelimumab [31], and that certain signaling pathways downstream of the TCR and cytokine receptor were also influenced by CTLA-4 blockade, such as increased pp38, pSTAT1 and pSTAT3, and decreased pLck, pERK1/2 and pSTAT5 levels [32]. CTLA-4 blockade also induced cell proliferation in the spleen, a secondary lymphoid organ, shown by molecular imaging with the PET probe 18 F-FLT [33]. Those investigators also reported significantly increased intratumoral $\mathrm{CD}_{4}^{+}$and mostly $\mathrm{CD}^{+} \mathrm{T}$ cell infiltration, with increased HLA-DR and CD45RO double positive cells in post tremelimumab biopsies [34] and increased expression of FoxP3.

To date, the molecular basis and mechanisms of action of ipilimumab have not been documented systematically in vivo. There is a critical need for biomarkers of the effects of ipilimumab as well as potential predictive markers for clinical outcome and induction of irAE. Therefore, in the current study we investigated the effects of ipilimumab on the gene expression profile of $\mathrm{CD}^{+}$and $\mathrm{CD}^{+} \mathrm{T}$ cells by microarray analysis when it was administered as adjuvant therapy to 12 patients in a trial for patients with high risk resected melanoma. We further clarified the immunophenotypic changes induced by ipilimumab on $\mathrm{CD}^{+}$and $\mathrm{CD} 8^{+} \mathrm{T}$ cells by a flow cytometry study of an expanded group of 37 patients and identified potential predictive biomarkers from pre-treatment specimens of 55 patients. Our studies provide evidence of candidate pre-treatment and PD biomarkers that merit further testing.

\section{Material and methods \\ Patients}

Between June 2004 and December 2008, 75 patients (39 at the University of Southern California, Norris Cancer Center and 36 at the Moffitt Cancer Center) with resected stage IIIC/IV melanoma received ipilimumab with or without a peptide vaccine. The demographic and clinic outcomes of the patients in the current study are shown in Table 1, which have been previously reported [26] with updated follow-up: three additional patients died (R DOD); one additional patient relapsed and was resected with no evidence of disease (R NED) instead of being NED. Toxicity was assessed by the National Cancer Institute Common Terminology Criteria for Adverse Events, version 3.0. The protocol was approved by the University of Southern California/Los Angeles County and University of South Florida Institutional Review Boards, and all patients provided written informed consent.

\section{PBMC collection, preparation and T cells purification}

Apheresis with exchange of 5 to 7 liters was performed within 1 week before and 6 months after the initiation of therapy, after four doses of ipilimumab. Heparinized blood was collected after 2 doses of ipilimumab, 3 months after the initiation of therapy. PBMC were 
Table 1 Demographics and treatment related variables of all patients in this study $(\mathbf{n}=\mathbf{5 5})$

\begin{tabular}{lll}
\hline Variable & Level & $\mathbf{n}(\%)$ \\
\hline gender & $\mathrm{F}$ & $21(38.2)$ \\
stage & $\mathrm{M}$ & $34(61.8)$ \\
& IIlc & $24(43.6)$ \\
HLA A2 & IV & $31(56.4)$ \\
& $\mathrm{A} 2+$ & $34(61.8)$ \\
dosage & $\mathrm{A} 2-$ & $21(38.2)$ \\
& $10 \mathrm{mg} / \mathrm{kg}$ & $40(72.7)$ \\
irAE & $3 \mathrm{mg} / \mathrm{kg}$ & $15(27.3)$ \\
& $\mathrm{N}$ & $31(56.4)$ \\
Outcome & Y & $24(43.6)$ \\
& NED & $35(63.6)$ \\
& Relapse & $20(36.4)$ \\
\hline
\end{tabular}

isolated from pre-, 3- and 6-month post-ipilimumab treatment specimens by Lymphoprep (Greiner Bio-One, Longwood, FL) density gradient centrifugation. PBMC were counted, then frozen in $90 \%$ heat inactivated human AB serum (HS, Omega Scientific, Tarzana, CA) and $10 \%$ dimethyl sulfoxide (DMSO) (Sigma, St Louis, $\mathrm{MO}$ ) and stored in secured liquid nitrogen freezers at $-168^{\circ} \mathrm{C}$ until use.

Cryopreserved pre- and 6-month post-treatment PBMC from each patient were thawed immediately into pre-warmed AIM-V media (Invitrogen Corporation, Grand Island, NY) supplemented with 5\% HS. For microarray analysis, PBMCs were sorted as follows: cells were stained with CD3-FITC (BD Bioscience, San Diego, CA), CD4-PE (BD Bioscience), CD8-APC (BD Bioscience) for $30 \mathrm{~min}$ at $4^{\circ} \mathrm{C}$. After extensive washing, PBMCs were stained with DAPI nucleic acid dye (Invitrogen) to exclude dead and dying cells. After washing with staining buffer (PBS $+0.5 \% \mathrm{HS})$, PBMC were resuspended in staining buffer for flow cytometry sorting. $\mathrm{CD}^{+}{ }^{+} \mathrm{CD} 4^{+} \mathrm{CD}^{-}, \mathrm{CD}^{+} \mathrm{CD}^{+} \mathrm{CD}^{-} \mathrm{T}$ cells cell populations were collected by Aria (BD Bioscience, San Jose, CA). The purity of the sorted specific cell populations were consistently $\geq 99 \%$.

\section{Microarray analysis}

The sorted cells were pelleted and re-suspended in a RLT lysis buffer (Qiagen Science, Valencia, CA), and delivered to the Microarray Core (Moffitt Cancer Center, Tampa, FL) for expression array analysis. RNA from the sorted cell populations were DNase-treated and extracted using the Qiagen RNeasy mini-prep according to the manufacturer's protocol (Qiagen). The Nugen Message Amp Premier kit was used to amplify 100 nanograms of total RNA (Nugen Technologies, San Carlos, CA). Briefly, the extracted poly-
(A) RNA was specifically converted to cDNA, amplified and labeled with biotin following the procedure initially described by Van Gelder et al. [35]. Biotin-labeled cDNA was hybridized onto Affymetrix U133 Plus 2.0 microarrays. Microarray data were then analyzed using Affymetrix Expression Console. Gene detect calls were obtained using the Affymetrix MAS5 algorithm [36] to filter genes that are not expressed across the board and express value or signal intensity was calculated by the robust multi-array analysis method (RMA) developed by Irizarry et al [37]. Differential gene expressions were then assessed using Student's t-test and false discovery rate (FDR) was estimated [38].

\section{Surface and intracellular staining}

For cell surface staining, $1-2 \times 10^{6}$ PBMC in $100 \mu \mathrm{l}$ PBS were stained with the Aqua-live/dead fixable dye (Invitrogen) at $4^{\circ} \mathrm{C}$ for $30 \mathrm{~min}$. After washing, PBMC were stained with fluorochrome-conjugated antibodies against cell surface markers prepared as a master-mix-solution for $30 \mathrm{~min}$ at $4^{\circ} \mathrm{C}$. The antibodies for surface markers were purchased from BD Bioscience unless otherwise specified: CD3AlexFluor 700, CD4-PECy7, CD8-PERCPCy5.5, ICOS-PE, CCR7-FITC (R\&D Systems, Minneapolis, MN), CCR7-PE (R \& D Systems), CXCR3-FITC (R \& D Systems), CD109PE, CD45RA-FITC, CD28-APC (eBioscience, San Diego, CA), IL-7R-APC (R \& D system), CD25-FITC, TGFßR3-PE (R \& D Systems) and MIC-A-APC (R \& D Systems). The fluorescent-minus-one and isotype control were included in each experiment in order to appropriately set the gates. A total of 300,000 live single lymphocytes were acquired on a LSR II flow cytometer (BD Bioscience). Analysis gates were set on single live lymphocytes defined by scatter characteristics and Aqua negative staining. First, we gated lymphocytes by forward and side scatter, then gated on single cells by forward and sideward width and height. We observed single live lymphocytes by gating on aqua negatively stained single lymphocytes (Additional file 1: Figure S1 -row 1). In the whole study, we observed the biomarkers on/in $\mathrm{CD}_{4}^{+}$(Additional file 1: Figure S1-row 2, 3) and $\mathrm{CD}^{+} \mathrm{T}$ cells (Additional file 1: Figure S1-row 4, 5). The gating strategies for the biomarkers presented in this paper are shown in Additional file 1: Figure S1.

For intracellular staining, $2-3 \times 10^{6} \mathrm{PBMC}$ in $100 \mu \mathrm{l}$ staining buffer were treated as above, then fixed with a freshly prepared Fixation/Permeabilization working solution (eBioscience) at $4^{\circ} \mathrm{C}$ for $30 \mathrm{~min}$. After wash with permeabilization buffer (eBioscience), the cells were stained with intracellular markers: Ki67-FITC (Abcam, Cambridge, MA), EOMESodermin (EOMES)-Alex Fluor 647 (eBioscience), granzyme B-FITC, perforin-PE, FoxP3 APC (eBioscience), GATA 3-Alex Fluor 647 (eBioscience), cleaved caspase III-PE for $30 \mathrm{~min}$ at $4^{\circ} \mathrm{C}$. Cells were then 
washed in the permeabilization buffer and resuspended in staining buffer for flow cytometry acquistion.

For the standardization of flow cytometry assays and the consistency of daily performance, a normal PBMC sample was stained and run on flow cytometry in parallel with the subject samples and Spherotech rainbow fluorescent particles (Spherotech, Inc, Lake Forest, IL) were run before running samples for alignment of the optical system of the flow cytometer in each channel.

\section{Flow cytometry analysis}

Flow cytometry data were analyzed using Flowjo software (Version 9.0.2, Tree Star, Inc., Asland, OR). The mean fluorescence intensity (MFI) and percent of positive expression (\%) of each marker were measured for $\mathrm{CD}^{+}$and $\mathrm{CD}^{+}{ }^{+}$cells.

\section{Statistical analysis}

Descriptive summary statistics, e.g., frequency and \% for discrete variables and mean (standard deviation: SD), interquartiles and median (range) for continuous variables, were reported as appropriate. Both absolute change and fold change, i.e., post-pre and (post-pre)/pre, were analyzed to account for a potentially better normalization under the $\log$ scale for the immunological biomarkers under investigation. Median changes and interquartiles were reported for the biomarker change variables due to concerns on sometimes small sample sizes and the underlying normality assumption required for a valid confidence interval. Wilcoxon signed-rank test was used to test whether changes in immunological biomarker expression levels between pre-, to 3- and 6-month post-ipilimumab were statistically significant. Both point estimates and their confidence intervals (CIs) were provided for parameters of interest, e.g., odds ratio (OR). Confidence intervals were set at the 95\% level. Univariate logistic regression models were employed to explore the effects of baseline and absolute change as well as fold change of each biomarker on disease outcome (Relapsed vs. NED) and irAE (Yes vs. No). The CI for OR based on the univariate logistic regression model results was calculated for an increment that equals to one half of the interquartile range of the corresponding change variable for each of the biomarkers. Baseline biomarkers were also dichotomized using their respective medians and then correlated with the disease outcome (Relapsed vs. NED) and irAE (Yes vs. No) using the $2 \times 2$ contingency table approach. The resulting ORs, their CIs and Fisher test p-values were reported. The Kaplan-Meier product-limit analysis and log-rank test were employed to address the question of whether relapse-free survival was associated with any of the dichotomized biomarkers at baseline. A p-value of $\leq 0.05$ was considered statistically significant and no multiple comparison adjustments were made in this exploratory biomarker study except for the gene microarray part of the data analyses. All statistical analyses were performed using SAS version 9.

\section{Results}

\section{Gene expression of $\mathrm{CD}^{+}$and $\mathrm{CD}^{+} \mathrm{T}$ cells induced by ipilimumab}

To assess the effect of ipilimumab on overall gene expression in $\mathrm{CD}^{+}$and $\mathrm{CD} 8^{+} \mathrm{T}$ cells in vivo, microarray analysis was conducted on $\mathrm{T}$ cells purified by flow cytometry from PBMCs collected from 12 resected melanoma patients preand 6-month post-ipilimumab treatment (Additional file 1: Table S1). Differentially expressed genes were selected with a paired student $\mathrm{T}$-test $\mathrm{p}$-value of 0.03 or less $(\mathrm{p} \leq 0.03)$ and a fold change of the group mean of 1.2 or greater $(\geq 1.2)$ or 0.8 or less $(\leq 0.8)$. Table $2 \mathrm{a}$ and $2 \mathrm{~b}$ show some immune-related genes from the top differentially expressed genes in $\mathrm{CD}_{4}^{+}$and $\mathrm{CD} 8^{+} \mathrm{T}$ cells, respectively, after ipilimumab treatment. The genes were categorized by biological process and/or gene function: cell cycle, cytokine-related, chemokine-related, $\mathrm{T}$ cell activation and proliferation signal-related, survival and apoptotic signal-related, kinaserelated and heat shock protein family-related genes. It is worth noting that the genes most impacted by ipilimumab were cell cycle related in both $\mathrm{CD} 4^{+}$and $\mathrm{CD} 8^{+} \mathrm{T}$ cells. Ipilimumab appeared to release the arrested cell cycle in CD4 ${ }^{+}$and $\mathrm{CD}^{+} \mathrm{T}$ cells as evidenced by highly significant and consistent up-regulation of CDC2 (Table $2 \mathrm{a}$ and $2 \mathrm{~b}$ ), and other cell cycle related genes (data not shown).

\section{Pharmacodynamic effects of ipilimumab on T cells}

To verify changes in selected molecules from the microarray analysis and further investigate the mechanism of action of ipilimumab, a flow cytometry study was undertaken with the pre-, 3-month and 6-month post-ipilimumab PBMCs from expanded groups of 55, 25 and 37 patients, respectively (Table 2, Additional file 1: Table S1b and S1c), overlapping the microarray cohort of 12 but limited to all patients with sufficient PBMC available for analysis. In addition to the selected immunological biomarkers, we also measured $\mathrm{CD}^{+}$and $\mathrm{CD}^{+} \mathrm{T}$ cell effector-memory/naive phenotypes. We observed that naive $\mathrm{CD} 4^{+}$and $\mathrm{CD}^{+} \mathrm{T}$ cells $\left(\mathrm{CCR} 7^{+} \mathrm{CD} 45 \mathrm{RA}^{+}\right)$were significantly reduced 6 months after ipilimumab, with a corresponding significant increase in $\mathrm{CD}^{+}$central memory and $\mathrm{CD} 4^{+}$effector memory T cells (data not shown). We report below biomarkers that significantly changed both in absolute value and by fold change for $\%$ (positivity) with $\mathrm{p} \leq 0.02$ by Wilcoxon.

Increased Ki67 expression in, and ICOS on $\mathrm{CD}^{+}$and $\mathrm{CD}^{+}$ T cells 3 and 6 months after ipilimumab

The Ki-67 protein (also known as MKI67) is a cellular marker for proliferation [39] and cell cycling [40] and is an indicator of the growth fraction of a given cell 
Table 2 Microarray data for immune related genes from CD4 ${ }^{+} T$ cells (Table $2 a$ ) and CD8 ${ }^{+} T$ cells (Table $2 b$ ) with fold increases over baseline control samples, $p$-values for the differences indicated, FDR for the false discovery rate, and the mean \pm SD of pre and post samples for the gene expression ranges

\begin{tabular}{|c|c|c|c|c|c|c|}
\hline Gene symbol & Gene name & Fold-change & p-value & FDR & Pre-Mean \pm SD & Post-Mean \pm SD \\
\hline \multicolumn{7}{|c|}{ a. Genes impacted by ipilimumab in CD4+ T cells } \\
\hline \multicolumn{7}{|c|}{ Cell cycle related } \\
\hline \multirow[t]{2}{*}{ CDC2 } & cell division cycle 2, G1 to $\mathrm{S}$ and $\mathrm{G} 2$ to $\mathrm{M}$ & 1.98 & 0.009 & 0.0409 & $18.61 \pm 4.41$ & $36.92 \pm 21.36$ \\
\hline & & 2.78 & 0.0142 & 0.0432 & $66.68 \pm 59.31$ & $185.59 \pm 185.36$ \\
\hline TYMS & thymidylate synthetase & 2.77 & 0.0075 & 0.0408 & $129.75 \pm 58.10$ & $358.99 \pm 254.47$ \\
\hline CCNB2 & cyclin B2 & 2.08 & 0.0142 & 0.0434 & $28.17 \pm 11.75$ & $58.49 \pm 45.13$ \\
\hline CDK7 & cyclin-dependent kinase 7 & 1.26 & 0.0074 & 0.0408 & $214.08 \pm 75.01$ & $270.13 \pm 106.34$ \\
\hline \multicolumn{7}{|c|}{ Cytokines-related } \\
\hline \multirow[t]{2}{*}{ PGDS } & prostaglandin D2 synthase, hematopoietic & 2.2 & 0.0024 & 0.0393 & $14.20 \pm 5.42$ & $31.30 \pm 14.57$ \\
\hline & & 1.51 & 0.0048 & 0.04044 & $489.68 \pm 470.87$ & $740.39 \pm 581.83$ \\
\hline TGFBR3 & transforming growth factor $\beta$ RIII & 1.39 & 0.0111 & 0.0411 & $505.71 \pm 304.47$ & $701.22 \pm 246.45$ \\
\hline IFNy & interferon, $\gamma$ & 1.46 & 0.0255 & 0.0751 & $138.35 \pm 104.72$ & $201.55 \pm 120.78$ \\
\hline IL-7 & interleukin 7 & 1.28 & 0.0169 & 0.0511 & $15.43 \pm 10.42$ & $19.73 \pm 8.89$ \\
\hline STAT1 & signal transducer and activator of transcription 1 & 1.28 & 0.0081 & 0.0409 & $1141.96 \pm 330.11$ & $1460.67 \pm 577.64$ \\
\hline \multirow[t]{2}{*}{ SCYE1 } & small inducible cytokine subfamily $\mathrm{E}$, member 1 & 1.27 & 0.0103 & 0.041 & $278.24 \pm 100.74$ & $352.82 \pm 149.81$ \\
\hline & & 0.80 & 0.0061 & 0.0406 & $5219.38 \pm 1457.55$ & $4291.38 \pm 1772.32$ \\
\hline IL-7R & interleukin 7 receptor & 0.74 & 0.0011 & 0.0375 & $3309.89 \pm 1296.32$ & $2467.81 \pm 1094.22$ \\
\hline IL-2Ra & interleukin 2 receptor, a & 0.69 & 0.01811 & 0.0544 & $113.56 \pm 58.89$ & $79.12 \pm 39.28$ \\
\hline IL-15 & interleukin 15 & 0.74 & 0.0032 & 0.0398 & $54.76 \pm 39.59$ & $40.63 \pm 31.09$ \\
\hline TNFSF8 & tumor necrosis factor superfamily, member 8 & 0.73 & 0.0202 & 0.0605 & $248.08 \pm 148.25$ & $181.53 \pm 92.03$ \\
\hline \multicolumn{7}{|c|}{ Chemokines-related } \\
\hline \multirow[t]{2}{*}{ ITGB1 } & integrin, $\beta 1$ (antigen CD29) & 1.29 & 0.0055 & 0.0405 & $1449.91 \pm 772.02$ & $1867.82 \pm 802.10$ \\
\hline & & 1.20 & 0.0012 & 0.0375 & $396.68 \pm 336.59$ & $476.25 \pm 376.51$ \\
\hline CXCR3 & chemokine receptor 3 & 1.29 & 0.0286 & 0.0825 & $47.04 \pm 23.35$ & $60.53 \pm 33.18$ \\
\hline CXCR7 & chemokine receptor 7 & 0.75 & 0.0205 & 0.0614 & $83.62 \pm 25.83$ & $63.45 \pm 25.78$ \\
\hline ITGA6 & integrin, a6 & 0.72 & 0.0211 & 0.063 & $1166.8 \pm 1046.57$ & $837.4 \pm 796.19$ \\
\hline \multicolumn{7}{|c|}{ Activation, proliferation and differentiation-related } \\
\hline \multirow[t]{2}{*}{ MKI67 } & antigen identified by monoclonal antibody Ki-67 & 1.98 & 0.0165 & 0.0498 & $41.58 \pm 22.80$ & $82.16 \pm 62.67$ \\
\hline & & 1.69 & 0.0104 & 0.0410 & $19.37 \pm 9.50$ & $32.73 \pm 20.37$ \\
\hline ICOS & inducible T-cell costimulator & 1.49 & 0.0011 & 0.0375 & $587.76 \pm 294.69$ & $874.26 \pm 397.84$ \\
\hline \multirow[t]{2}{*}{ GATA3 } & GATA binding protein 3 & 1.43 & 0.0124 & 0.042 & $284.77 \pm 189.82$ & $406.03 \pm 268.34$ \\
\hline & & 1.37 & 0.0023 & 0.0392 & $163.55 \pm 83.74$ & $224.53 \pm 114.73$ \\
\hline CTLA-4 & cytotoxic T-lymphocyte-associated protein 4 & 1.37 & 0.0249 & 0.0734 & $511.58 \pm 260.28$ & $700.23 \pm 359.54$ \\
\hline MICA & MHC class I polypeptide-related sequence A & 0.7 & 0.0015 & 0.0379 & $120.33 \pm 67.61$ & $84.36 \pm 51.72$ \\
\hline \multicolumn{7}{|c|}{$\mathrm{BCL}$ family-related } \\
\hline $\mathrm{BCl} 3$ & B-cell CLL/lymphoma 3 & 1.56 & 0.0036 & 0.0400 & $199.55 \pm 112.65$ & $311.36 \pm 120.66$ \\
\hline \multirow[t]{2}{*}{ BAK1 } & Bcl2-antagonist/killer 1 & 1.26 & $2.00 \mathrm{E}-04$ & 0.0365 & $130.50 \pm 27.61$ & $164.92 \pm 33.45$ \\
\hline & & 1.24 & 0.0067 & 0.0407 & $314.36 \pm 77.54$ & $388.54 \pm 79.60$ \\
\hline BCl2L11 & Bcl2-like 11 & 1.21 & 0.0369 & 0.1053 & $442.48 \pm 299.18$ & $536.88 \pm 388.57$ \\
\hline \multirow[t]{2}{*}{ BCLAF1 } & Bcl2-associated transcription factor 1 & 1.21 & 0.0234 & 0.0695 & $61.14 \pm 14.91$ & $73.89 \pm 26.64$ \\
\hline & & 0.72 & 0.0158 & 0.0479 & $189.15 \pm 81.00$ & $137.91 \pm 40.11$ \\
\hline $\mathrm{BCl} 2$ & B-cell CLL/lymphoma 2 & 0.63 & 0.0050 & 0.0404 & $427.68 \pm 327.43$ & $272.97 \pm 207.62$ \\
\hline
\end{tabular}


Table 2 Microarray data for immune related genes from $\mathrm{CD}^{+} \mathrm{T}$ cells (Table $2 \mathrm{a}$ ) and CD8 ${ }^{+} \mathrm{T}$ cells (Table $2 \mathrm{~b}$ ) with fold increases over baseline control samples, $p$-values for the differences indicated, FDR for the false discovery rate, and the mean \pm SD of pre and post samples for the gene expression ranges (Continued)

\begin{tabular}{|c|c|c|c|c|c|c|}
\hline \multicolumn{7}{|c|}{ Apoptosis, MAP kinase and protein kinase-related } \\
\hline ANXA5 & annexin 5 & 1.32 & 0.0271 & 0.0794 & $599.68 \pm 269.08$ & $793.89 \pm 425.06$ \\
\hline MAPK6 & mitogen-activated protein kinase 6 & 1.31 & 0.0261 & 0.0768 & $209.49 \pm 142.30$ & $273.63 \pm 202.36$ \\
\hline PPP1CC & protein phosphatase 1 , catalytic subunit, $\gamma$ isoform & 1.23 & 0.0152 & 0.0462 & $998.56 \pm 432.59$ & $1225.87 \pm 571.01$ \\
\hline CASP7 & caspase 7 , apoptosis-related cysteine peptidase & 1.22 & 0.0145 & 0.0441 & $141.11 \pm 41.72$ & $171.83 \pm 48.77$ \\
\hline MAP2K6 & mitogen-activated protein kinase kinase kinase 6 & 0.77 & 0.0105 & 0.0410 & $77.3 \pm 41.24$ & $59.77 \pm 33.17$ \\
\hline ANXA11 & annexin 11 & 0.75 & 0.0003 & 0.0368 & $93.23 \pm 20.45$ & $70.21 \pm 31.98$ \\
\hline ATF7 & activating transcription factor 7 & 0.75 & 0.0252 & 0.0743 & $170.44 \pm 120.64$ & $128.30 \pm 107.21$ \\
\hline MAP4K4 & mitogen-activated protein kinase kinase kinase 4 & 0.63 & 0.0095 & 0.041 & $137.49 \pm 51.60$ & $86.97 \pm 29.96$ \\
\hline \multicolumn{7}{|c|}{ b. Genes impacted by ipilimumab in $C D 8^{+} \mathrm{T}$ cells } \\
\hline \multicolumn{7}{|c|}{ Cell cycle-related } \\
\hline CDC2 & cell division cycle 2, G1 to $S$ and $G 2$ to $M$ & 1.81 & 0.03 & 0.0897 & $18.37 \pm 6.09$ & $33.23 \pm 21.15$ \\
\hline CDCA7 & Cell division cycle associated 7 & 1.67 & 0.0113 & 0.0647 & $87.63 \pm 93.37$ & $146.50 \pm 111.23$ \\
\hline \multicolumn{7}{|c|}{ Cytokines-related } \\
\hline TNFSF4 & tumor necrosis factor superfamily, member 4 & 0.58 & 0.0082 & 0.0647 & $40.88 \pm 27.10$ & $23.93 \pm 14.71$ \\
\hline \multicolumn{7}{|c|}{ Chemokines-related } \\
\hline ITGAV & integrin, aV (antigen CD51) & 0.80 & 5.00E-04 & 0.0647 & $114.65 \pm 54.10$ & $91.78 \pm 42.91$ \\
\hline \multicolumn{7}{|c|}{ Activation, Differentiation and Interaction-related } \\
\hline \multirow[t]{2}{*}{ HLA-DRB4 } & major histocompatibility complex, class II, DR $\beta 4$ & 1.4 & 0.0163 & 0.0647 & $28.04 \pm 26.29$ & $39.18 \pm 37.40$ \\
\hline & & 1.39 & 0.0100 & 0.0647 & $178.84 \pm 104.07$ & $248.93 \pm 148.36$ \\
\hline GATA3 & GATA binding protein 3 & 1.35 & 0.0026 & 0.0647 & $139.84 \pm 44.14$ & $188.83 \pm 75.51$ \\
\hline HLA-DRA & major histocompatibility complex, class II, DR a & 1.38 & 0.0193 & 0.0647 & $540.53 \pm 402.57$ & $745.47 \pm 350.32$ \\
\hline CD6 & CD6 molecule (CD166 receptor) & 1.32 & 0.0248 & 0.0754 & $179.47 \pm 95.79$ & $236.58 \pm 157.76$ \\
\hline CD5 & CD5 molecule & 1.22 & 0.0181 & 0.0647 & $103.58 \pm 38.21$ & $126.47 \pm 45.17$ \\
\hline EOMES & Eomesodermin & 0.69 & 0.0292 & 0.0877 & $1063.26 \pm 642.42$ & $738.05 \pm 445.38$ \\
\hline \multicolumn{7}{|c|}{ Apoptosis, MAP Kinases-related } \\
\hline TIAM1 & T-cell lymphoma invasion and metastasis 1 & 1.68 & 0.0105 & 0.0647 & $83.63 \pm 67.00$ & $140.61 \pm 116.68$ \\
\hline ANXA5 & annexin 5 & 1.31 & 0.0114 & 0.0647 & $576.93 \pm 278.33$ & $747.53 \pm 316.78$ \\
\hline API5 & apoptosis inhibitor 5 & 1.24 & 0.0088 & 0.0647 & $187.92 \pm 118.48$ & $233.04 \pm 151.93$ \\
\hline
\end{tabular}

Increases of greater than 1.2 fold and decreases of 0.8 fold or less are shown. Multiple values refer to different expressed sequence tags from the same gene.

population. As demonstrated in Table $3 \mathrm{a}$ and Table 3b, the $\%$ of $\mathrm{Ki} 67^{+} / \mathrm{CD}^{+}$and $\mathrm{Ki} 67^{+} / \mathrm{CD}^{+} \mathrm{T}$ cells were significantly increased in both 3-month and 6-month posttreatment PBMCs with $\mathrm{p} \leq 0.0009$ for all by Wilcoxon test and a median fold-increase ranging from 0.54 to 1.50. The increase in $\mathrm{Ki} 67^{+} / \mathrm{CD}^{+}{ }^{+} \mathrm{T}$ cells was higher at 3-month post ipilimumab treatment than at 6-month post treatment, but the increase of $\mathrm{Ki} 67^{+} / \mathrm{CD}^{+} \mathrm{T}$ cells was higher at 6-month post ipilimumab than at 3-month post ipilimumab.

ICOS is a T cell surface molecule structurally related to CD28 and CTLA-4 [41]. It is expressed at low levels on resting naïve $\mathrm{T}$ cells and is rapidly up-regulated following TCR ligation and CD28 costimulation [42]. After ipilimumab treatment, ICOS was increased significantly on $\mathrm{CD}_{4}^{+}$and $\mathrm{CD}^{+} \mathrm{T}$ cells in both 3-month and 6month post-treatment PBMCs $(\mathrm{p} \leq 0.0001$ with a median fold-increase of 1.34 to 2.90), with higher increases on $\mathrm{CD}^{+}$than on $\mathrm{CD}^{+} \mathrm{T}$ cells and higher absolute increases at 3-month than at 6-month post-treatment (Table $3 \mathrm{a}$ and $3 \mathrm{~b}$ ).

\section{Decreased CCR7 on $\mathrm{CD}^{+}$and $\mathrm{CD}^{+}{ }^{+} \mathrm{T}$ cells after ipilimumab}

The $\%$ of $\mathrm{CCR}^{+} / \mathrm{CD}^{+} \mathrm{T}$ cells was decreased at 3-month post-ipilimumab ( $\mathrm{p} \leq 0.018$ with a median fold-decrease of 0.14 , Table 3a). Similarly, the $\%$ of $\mathrm{CCR}^{+} / \mathrm{CD}^{+} \mathrm{T}$ cells was down-regulated at 6-month post-ipilimumab treatment $(\mathrm{p} \leq 0.006$ with a median fold-decrease of 0.03 , Table 3b). 
Table 3 Flow cytometry data for different phenotypic biomarkers from CD4 or CD8 T cells with absolute changes and fold-changes over baseline control samples at 3- (Table 3a) and 6-month (Table 3b) post ipilimumab with p-values for the differences shown

\begin{tabular}{|c|c|c|c|c|c|}
\hline Biomarker & $\mathbf{n}$ & Median change * $(\mathrm{Q} 1, \mathrm{Q} 3)$ & Wilcoxon p-value & Median foldchange * $(\mathrm{Q} 1, \mathrm{Q} 3)$ & Wilcoxon p-value \\
\hline \multicolumn{6}{|c|}{ a. Statistical analysis of changes in biomarkers at 3 months } \\
\hline$\%-I C O S-C D 4$ & 25 & $13.00(1.15,20.69)$ & $<.0001$ & $1.35(0.23,3.62)$ & $<.0001$ \\
\hline$\%-I C O S-C D 8$ & 25 & $4.19(2.07,7.75)$ & $<.0001$ & $2.90(1.25,6.72)$ & $<.0001$ \\
\hline \%-Ki67-CD4 & 24 & $3.62(0.74,6.94)$ & $<.0001$ & $1.50(0.18,2.64)$ & $<.0001$ \\
\hline \%-Ki67-CD8 & 24 & $1.49(-0.10,4.86)$ & 0.0009 & $0.54(-0.03,2.20)$ & 0.0003 \\
\hline$\%-C C R 7-C D 8$ & 25 & $-3.98(-11.40,1.30)$ & 0.0122 & $-0.14(-0.27,0.04)$ & 0.018 \\
\hline$\%-C D 25-C D 8$ & 25 & $-1.60(-5.68,-0.70)$ & $<.0001$ & $-0.42(-0.56,-0.25)$ & $<.0001$ \\
\hline \multicolumn{6}{|c|}{ b. Statistical analysis of changes in biomarkers at 6 months } \\
\hline$\%-I C O S-C D 4$ & 37 & $9.45(3.13,14.57)$ & $<.0001$ & $1.66(0.70,2.42)$ & $<.0001$ \\
\hline$\%-I C O S-C D 8$ & 37 & $3.07(1.62,5.36)$ & $<.0001$ & $1.34(0.63,3.30)$ & $<.0001$ \\
\hline$\%-K i 67-C D 4$ & 35 & $2.33(1.37,6.97)$ & $<.0001$ & $0.87(0.29,2.12)$ & $<.0001$ \\
\hline \%-Ki67-CD8 & 36 & $1.88(0.13,4.91)$ & 0.0004 & $0.55(0.04,1.52)$ & $<.0001$ \\
\hline \%-Gata3-CD4 & 28 & $3.76(0.28,8.04)$ & 0.0004 & $0.94(-0.01,1.62)$ & $<.0001$ \\
\hline \%-Gata3-CD8 & 28 & $2.07(0.59,4.02)$ & 0.0006 & $0.59(0.09,1.23)$ & $<.0001$ \\
\hline$\%$-CCR7-CD4 & 37 & $-2.90(-6.80,-0.40)$ & 0.0017 & $-0.03(-0.09,-0.01)$ & 0.006 \\
\hline
\end{tabular}

* $(\mathrm{Q} 1, \mathrm{Q} 3)$ are first and third interquartiles.

\section{Decreased CD25 on $\mathrm{CD}^{+}$after ipilimumab}

CD25 is a T cell activation marker, the \% of CD25 expression on $\mathrm{CD}^{+} \mathrm{T}$ cells were decreased at 3-month post-ipilimumab ( $\mathrm{p} \leq 0.0001$ with a median fold-decrease of 0.42 , Table $3 a)$.

\section{Increased GATA3 expression in $\mathrm{CD}^{+}$and $\mathrm{CD}^{+} \mathrm{T}$ cells}

GATA3 is a transcription factor that is a marker for Th2 polarization and is associated with the generation of Th2 cytokines IL-4, IL-5 and IL-10. After treatment with ipilimumab, GATA3 expression was increased significantly in $\mathrm{CD}^{+}$and $\mathrm{CD}^{+} \mathrm{T}$ cells at 6 -month post-ipilimumab treatment $(\mathrm{p} \leq 0.0006$ with a median fold-increase of 0.94 and 0.59 , Table $3 \mathrm{~b})$.
Surrogate biomarkers on/in T cells associated with relapse or irAE

In an univariable logistic regression analysis using changes in expression by flow cytometry as a continuous variable one at a time, only absolute decreases in $\%$ of $\mathrm{Ki} 67^{+} \mathrm{EOMES}^{+} \mathrm{CD} 4^{+}$ and $\%$ of $\mathrm{CCR}^{+} \mathrm{CD}^{+}$, and increases in $\%$ of $\mathrm{EOMES}^{+} \mathrm{CD} 8^{+}$ and $\%$ of GranzymeB ${ }^{+} \mathrm{EOMES}^{+} \mathrm{CD}^{+}{ }^{+}$cells were associated with a higher odds of relapse with $\mathrm{p}<0.04$ (OR for increment of half the interquartile range of the corresponding change ranging from 0.17 to 0.50 for the negative association and from 2.63 to 5.00 for the positive association, Table $4 \mathrm{a}$ ). Only absolute decrease in $\%$ of $\mathrm{Ki}^{+} \mathrm{CD}^{+} \mathrm{T}$ cells was associated with a development of irAE with $\mathrm{p}=0.02(\mathrm{OR}=0.47$, Table 4b).

Table 4 Association of phenotypic changes on T cells with clinical outcome (Relapse vs. NED) (Table 4a) and irAE (Yes vs. No) (Table 4b) was based on univariable logistic regression modeling

\begin{tabular}{|c|c|c|c|c|c|}
\hline Biomarker & $\mathbf{n}$ & Slope & p-value & $1 / 2$ IQR & OR $(95 \% \mathrm{Cl})$ \\
\hline \multicolumn{6}{|c|}{ a. Association of changes in biomarkers at 6 months with outcome (Relapse vs. NED) } \\
\hline$\%-\mathrm{Ki} 67+\mathrm{EOMES}+\mathrm{CD} 4+$ & 19 & -3.5232 & 0.0285 & 0.5 & $0.17(0.04,0.83)$ \\
\hline$\%-C C R 7+C D 8+$ & 37 & -0.0947 & 0.0379 & 7.4 & $0.50(0.260 .96)$ \\
\hline$\%-E O M E S+C D 8+$ & 36 & 0.1758 & 0.0072 & 5.5 & $2.63(1.30,5.32)$ \\
\hline$\%$ EOMES + GranzymeB + CD8+ & 19 & 0.2774 & 0.0293 & 5.8 & $5.00(1.18,21.23)$ \\
\hline \multicolumn{6}{|c|}{ b. Association of changes in biomarkers at 6 months with irAE (Yes vs. No) } \\
\hline \%-Ki67 + CD8+ & 36 & -0.3167 & 0.0217 & 2.4 & $0.47(0.24,0.89)$ \\
\hline
\end{tabular}

A total of 37 paired specimens of PBMC prior to and after four doses of ipilimumab were analyzed by flow cytometry for the indicated markers. CCR7 was stained extracellularly, EOMES, granzyme B and Ki67 were stained intracellularly per Materials and Methods. 
Table 5 a, Association between outcome (Relapse vs. NED) and dichotomized biomarkers at baseline. b, Association of baseline dichotomized biomarkers with irAE (Yes vs. No) for a total 55 patients

\begin{tabular}{|c|c|c|c|c|}
\hline Biomarker & Outcome & n (\%) & $\begin{array}{l}\text { Odds Ratio } \\
(95 \% \mathrm{Cl})\end{array}$ & $\begin{array}{l}\text { Fisher } \\
\text { p-value }\end{array}$ \\
\hline \multicolumn{5}{|c|}{ a. Association between outcome (Relapse/NED) and dichotomized baseline biomarkers by median } \\
\hline$\%-K i 67+$ EOMES + CD8+ $(n=39)$ & & & $11.25(2.52,50.27)$ & 0.0012 \\
\hline$<=2.11$ & Relapse & $15(75.0)$ & & \\
\hline$<=2.11$ & NED & $5(25.0)$ & & \\
\hline$>2.11$ & Relapse & $4(21.1)$ & & \\
\hline$>2.11$ & NED & $15(78.9)$ & & \\
\hline$\%$-EOMES + CD8+ $(n=54)$ & & & $3.77(1.16,12.27)$ & 0.0473 \\
\hline$<=55.6$ & Relapse & $14(51.9)$ & & \\
\hline$<=55.6$ & NED & $13(48.1)$ & & \\
\hline$>55.6$ & Relapse & $6(22.2)$ & & \\
\hline$>55.6$ & NED & $21(77.8)$ & & \\
\hline \multicolumn{5}{|c|}{ b. Association between irAE (Yes/No) and dichotomized baseline biomarkers by median } \\
\hline$\%-K i 67+$ EOMES + CD4+ $(n=39)$ & & & $8.00(1.74,36.70)$ & 0.0079 \\
\hline$<=0.446$ & Yes & $12(60.0)$ & & \\
\hline$<=0.446$ & No & $8(40.0)$ & & \\
\hline$>0.446$ & Yes & $3(15.8)$ & & \\
\hline$>0.446$ & No & $16(84.2)$ & & \\
\hline
\end{tabular}

Ki67 and EOMES that was stained intracellularly in a total of 36 paired specimens of PBMC prior to and after four doses of ipilimumab was analyzed by flow cytometry.

Pre-treatment biomarkers on/in T cells associated with outcome and irAE

An analysis of biomarkers at baseline dichotomized by their medians revealed that a low $\%$ of $\mathrm{Ki}^{+} \mathrm{EOMES}^{+}$ $\mathrm{CD}^{+} \mathrm{T}$ cells, and a low $\%$ of $\mathrm{EOMES}^{+} \mathrm{CD}^{+} \mathrm{T}$ cells were significantly associated with relapse $(\mathrm{p}=0.001$, and 0.047 with $\mathrm{OR}=11.25$, and 3.77, respectively; Table 5a). These pre-treatment biomarkers were also confirmed in a univariate logistic regression analysis to be associated with relapse (data not shown). A similar analysis of dichotomized baseline biomarkers by their medians showed that a low \% of $\mathrm{Ki} 67^{+} \mathrm{EOMES}^{+} \mathrm{CD} 4^{+} \mathrm{T}$ cells was associated with occurrence of irAE ( $p=0.008$ with $\mathrm{OR}=8.00$, Table $5 \mathrm{~b}$ ).

\section{Pre-treatment biomarkers on/in T cells associated with RFS}

Our analysis highlighted the potential importance of EOMES, a transcription factor in the T-box family and involved in the regulation of INF- $\gamma$, granzyme B and perforin production by $\mathrm{CD}^{+} \mathrm{T}$ cells [43]. To better understand the potential role of $\mathrm{EOMES}^{+} \mathrm{CD}^{+} \mathrm{T}$ cells in ipilimumab treatment, we stratified pre-treatment specimens by the median $\%$ of $\mathrm{EOMES}^{+} \mathrm{CD} 8^{+} \mathrm{T}$ cells. Patients with higher baseline $\%$ of $\mathrm{EOMES}^{+} \mathrm{CD}^{+} \mathrm{T}$ cells had a significantly improved relapse-free survival (RFS) compared to those with a lower basal level of $\mathrm{EOMES}^{+} \mathrm{CD}^{+} \mathrm{T}$ cells ( $p=0.02$ by log-rank test, Figure $1 \mathrm{a})$. The patients were also a

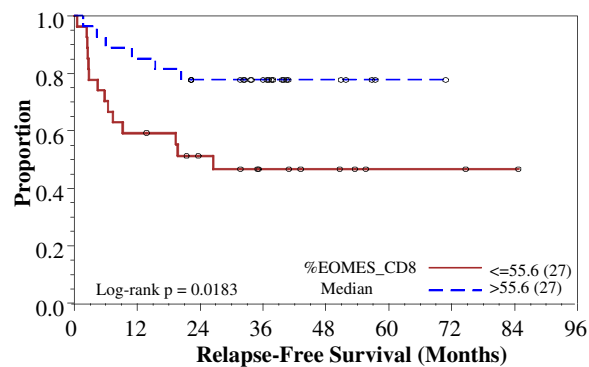

b

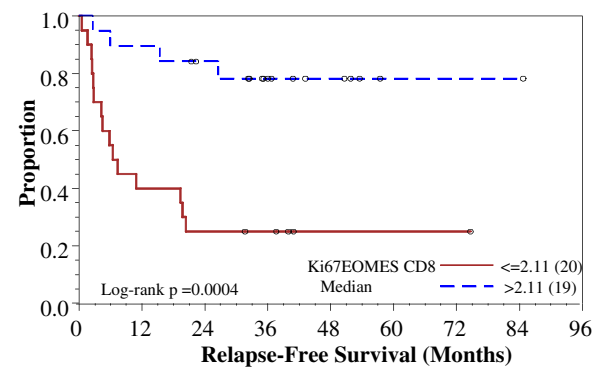

Figure 1 a: Kaplan-Meier relapse-free survival curves comparing patients with (high) greater than median baseline $\%$ of EOMES ${ }^{+} \mathrm{CD}^{+}$ to patients with (low) less than median $\%$ of EOMES ${ }^{+} \mathrm{CD}^{+}$. $\mathbf{b}$, Kaplan-Meier relapse-free survival curves comparing patients with high baseline $\%$ of $\mathrm{Ki}^{6} 7^{+} \mathrm{EOMES}^{+} / \mathrm{CD}^{+}$to patients with low $\%$ of $\mathrm{Ki}^{+} 7^{+} \mathrm{EOMES}^{+} / \mathrm{CD}^{+}$. 
stratified by the median \% of $\mathrm{Ki}^{+} 7^{+} \mathrm{EOMES}^{+} \mathrm{CD} 8^{+} \mathrm{T}$ cells. Patients with a higher proportion of $\mathrm{Ki}^{+} 7^{+} \mathrm{EMMES}^{+} \mathrm{CD} 8^{+} \mathrm{T}$ cells had significantly improved RFS compared with those with a lower $\%$ of $\mathrm{Ki}^{+} \mathrm{EOMES}^{+} \mathrm{CD}{ }^{+} \mathrm{T}$ cells $(\mathrm{p}=0.0004$, Figure 1b).

We also assessed these biomarkers in 11 pheresis specimens from normal donors as a reference. Levels of the most significant biomarker-\% of $\mathrm{EOMES}^{+} \mathrm{Ki} 67^{+} \mathrm{CD} 8^{+} \mathrm{T}$ cells from the 11 normals and the 55 melanoma patients in this trial are presented in Additional file 1: Figure S2. The median \% of EOMES ${ }^{+} \mathrm{Ki}_{6} 7^{+} \mathrm{CD}^{+}{ }^{+} \mathrm{T}$ cells for the 11 normals was 1.57 , very similar to the median of 1.50 for the relapsed patients (Wilcoxon Rank-sum test $\mathrm{p}=0.38$ ). For the NED group, the median $\%$ of $\mathrm{EOMES}^{+} \mathrm{Ki} 7^{+} \mathrm{CD} 8^{+}$ $\mathrm{T}$ cells was 2.50 , significantly higher than that of relapsed patients $(p=0.003)$ as well as that of the normal patient specimen $(\mathrm{p}=0.026)$.

\section{Discussion}

In the current study, we utilized an expression microarray analysis of flow cytometry-purified $\mathrm{CD}_{4}^{+}$and CD8 ${ }^{+} \mathrm{T}$ cells to define immunologically important gene products expressed by $\mathrm{T}$ cells from patients with high-risk melanoma that were significantly altered after ipilimumab. We then investigated selected $\mathrm{T}$ cell markers by performing flow cytometry analysis of membrane-bound and intra-cellular determinants using a larger group of samples, including 25 sets of pre-, 3-month, and 37 sets of pre- and 6-month post-treatment PBMCs and 55 pretreatment PBMC samples. We aimed to define potential biomarkers for ipilimumab treatment and determine if they were associated with clinical outcome and induction of irAE. The patients' age, gender, disease stage and the dosage of ipilimumab ( $3 \mathrm{vs} .10 \mathrm{mg} / \mathrm{kg}$ ) were not significantly associated with either outcome or irAE, nor did they significantly impact on the studied biomarkers (data not shown).

Previous investigations have focused on observations in peripheral blood or tumors from patients who have received CTLA-4 antibodies. CTLA-4 abrogation is expected to result in diffuse $\mathrm{CD}^{+}$and $\mathrm{CD}^{+} \mathrm{T}$ cell expansion and activation, based on the extensive lymphoid hypertrophy seen in the CTLA-4-/- knockout mice, and on the rise in ALC commonly observed in patients receiving ipilimumab. Several investigators described increases in $\mathrm{CD}_{4}^{+} \mathrm{HLA}-\mathrm{DR}^{+}$activated $\mathrm{T}$ cells, reductions in naïve $\mathrm{T}$ cells and an increase in central memory cells in those patients. In the current study, we also observed similar changes (data not shown). Augmented Th17 cells and increases in $\mathrm{CD}_{4}^{+} \mathrm{ICOS}^{+}$cells have also been described after CTLA-4 blockade, however no detailed analysis has explored the effects of CTLA-4 blocking antibodies on the expression of different immune markers on T cells.
In the current work, a number of biomarkers on and in $\mathrm{T}$ cells were significantly elevated after repeated injections of ipilimumab. Increased ICOS on $\mathrm{CD}^{+}$and $\mathrm{CD}^{+} \mathrm{T}$ cells was a pharmacodynamic marker for ipilimumab treatment, confirming results from prior studies. Increased $\mathrm{CD}^{+} \mathrm{ICOS}^{\mathrm{Hi}} \mathrm{T}$ cells have been reported to infiltrate tumor tissues and are found in peripheral blood after ipilimumab. In a small number of patients, a significant increase of $\mathrm{CD}^{+} \mathrm{ICOS}^{\mathrm{Hi}}$ and $\mathrm{CD}^{+} \mathrm{ICOS}^{\mathrm{Hi}} \mathrm{T}$ cells was observed at weeks 3 and 7. By week 24, CD4 $4^{+} \mathrm{ICOS}^{\mathrm{Hi}}$ $\mathrm{T}$ cells had returned to baseline values. Increased ICOS on $\mathrm{CD}^{+} \mathrm{T}$ cells was more pronounced after treatment with ipilimumab at $10 \mathrm{mg} / \mathrm{kg} /$ dose, with concomitant increases in $\mathrm{CD}^{+} \mathrm{ICOS}^{\mathrm{Hi}} \mathrm{T}$ cells which were not observed after treatment with the $3 \mathrm{mg} / \mathrm{kg} / \mathrm{dose}$ of antibody. In that small study, a sustained increase in frequency of $\mathrm{CD}^{+} \mathrm{ICOS}^{\mathrm{Hi}} \mathrm{T}$ cells was associated with overall survival at week 24 [27]. Our current study is consistent with a significant increase of ICOS expression on both $\mathrm{CD}^{+}$and $\mathrm{CD}^{+} \mathrm{T}$ cells not only at 3 - but also at 6- months (24 weeks) post ipilimumab independent of age, sex, metastatic stage of disease, or dose of ipilimumab. Changes in ICOS expression on CD4 or CD8 $\mathrm{T}$ cells were not associated with clinical outcome in our analysis. ICOS is not necessary for Th17 differentiation, but it is required for the expansion of the Th17 compartment [44]. ICOS expressing cells may also demonstrate anti-tumor reactivity and be responsible in part for the anti-tumor effects of ipilimumab [45].

We observed that ipilimumab resulted in consistently elevated Ki-67, a nuclear proliferation marker, in both $\mathrm{CD}^{+}$and $\mathrm{CD}^{+} \mathrm{T}$ cells 3 - and 6- month post ipilimumab. Interestingly, there was no alteration observed in the frequency of Ki67 positive cells among tumor infiltrating lymphocytes when post -tremelimumab biopsies were compared to baseline biopsies [34]. The reason for increased $\mathrm{Ki}-67$ in $\mathrm{CD}^{+}$and $\mathrm{CD}^{+} \mathrm{T}$ cells in peripheral blood, but not in the tumor site might be due to the differences in the CTLA-4 blocking antibodies or the different time points for sample harvesting, or lymphocytes may proliferate in lymphoid organs [33] and the peripheral blood compartment before they infiltrate into tumor sites.

The activation marker ICOS, proliferation marker Ki67, and the Th2 polarizing transcription factor GATA3 were also elevated on $\mathrm{CD}^{+}$and $\mathrm{CD}^{+} \mathrm{T}$ cells, suggesting that prolonged CTLA-4 blockade induced the generalized expansion of activated $\mathrm{T}$ cells that might generate Th2 cytokines IL-4, IL-5 and IL-10. Elevated levels of T cell IFN- $\gamma$ were detected on the microarray analysis, in contradistinction to the increase in GATA3. The observation that CCR7 was decreased on $\mathrm{CD}^{+}$and $\mathrm{CD}^{+} \mathrm{T}$ cells was consistent with the diminution of naïve $\mathrm{T}$ cells in the circulation. 
Novel findings from the current study were that a variety of immune markers either rose or declined on $\mathrm{CD} 4^{+}$ and $\mathrm{CD}^{+} \mathrm{T}$ cells after treatment with ipilimumab. The microarray data defined a larger group of altered genes that increased by at least 1.2 fold or decreased by 0.8 fold in the $\mathrm{CD} 4^{+}$cells than in $\mathrm{CD}^{+} \mathrm{T}$ cells, suggesting that effects of CTLA-4 blockade with ipilimumab were predominantly on the $\mathrm{CD}^{+}{ }^{+} \mathrm{T}$ cell population. CTLA-4 signals block the lymphocyte cell cycle at the G1 to S transition. Ipilimumab released the cell cycle arrest of $\mathrm{CD}^{+}{ }^{+}$and $\mathrm{CD} 8^{+} \mathrm{T}$ cells, as demonstrated by the significant alteration of a group of cell cycle genes (data not shown).

Our data are consistent with other studies showing that the effects of CTLA-4 blockade are more prominent on $\mathrm{CD}_{4}^{+} \mathrm{T}$ cells, and that $\mathrm{T}$ lymphocytes are broadly expanded. Our data on the association of relapse with phenotypic changes on $\mathrm{CD}^{+} \mathrm{T}$ cells are novel and point to the importance of this cell population in the mechanism of ipilimumab's anti-tumor effect. The use of microarrays and $\mathrm{T}$ cell phenotypic analysis to confirm the changes in gene expression would not have detected the alterations seen in detailed phosphoflow assays by Comin-Anduix et al [32]. Interestingly, the microarray analysis in the current work did not show that major alterations were seen in downstream TCR and cytokine signaling molecules, so we cannot confirm or refute their data. We did not see significant changes in FoxP3 or GITR expression, consistent with our own and others' work, nor were cytokine levels appreciably altered other than gamma interferon. While we focused on the effects of ipilimumab on $\mathrm{T}$ cells as an effective immunotherapeutic agent, it might also have a wider impact on the immune system, not only on $\mathrm{CD} 4^{+}$and $\mathrm{CD} 8^{+} \mathrm{T}$ cells as in our current study, but also on $\mathrm{CD} 14^{+}$monocytes [32] and B cells [46].

Ipilimumab may also rescue tumor-impaired IFN- $\gamma$ pathways in $\mathrm{CD}^{+} \mathrm{T}$ cells [47], since a number of genes associated with IFN- $\gamma$ signals such as STAT1, ISG15, GBp1, and EIF2AK2 were up-regulated by ipilimumab (data not shown). Up-regulation of STAT1 has been confirmed by phosphoflow [32] after tremelimumab.

Eomesodermin (EOMES) is an important transcription factor controlling the function of effector $\mathrm{CD}^{+} \mathrm{T}$ cells [43]. The expression of EOMES in $\mathrm{CD}^{+} \mathrm{T}$ cells may reflect a critical basal level of immune competence of the melanoma patient. $\mathrm{CD}^{+} \mathrm{T}$ cells play a vital role in the immune response to melanoma, and their baseline level of activation and function may be a sine qua non for the therapeutic effect of ipilimumab. CTLA-4 signaling may specifically target EOMES resulting in reduced IFN- $\gamma$ and granzyme B expression by selectively inhibiting accumulation of EOMES mRNA and protein [48]. Ectopic expression of EOMES reversed CTLA-4 mediated inhibition of effector molecules, and CTLA- $4^{-} / \mathrm{CD}^{+} \mathrm{T}$ cells had greatly enhanced IFN- $\gamma$ and granzyme B production, as well as enhanced cytolytic function and increased expression of EOMES [48]. The increase in IFN- $\gamma$ signals and up-regulated \% of granzyme B expression on EOMES $^{+} / \mathrm{CD}^{+} \mathrm{T}$ cells $(\mathrm{p}=0.003$, data not shown $)$ in our current study would suggest ipilimumab interferes with the down-regulation of EOMES and its downstream signals, IFN- $\gamma$ and granzyme B, that is mediated by CTLA- 4 engagement. The pre-treatment expression of EOMES in $\mathrm{CD}^{+} \mathrm{T}$ cells and the level of $\mathrm{Ki} 67^{+} \mathrm{EOMES}^{+} \mathrm{CD}^{+} \mathrm{T}$ cells are indices that appear to be associated with decreased risk of relapse and prolonged RFS after adjuvant treatment with ipilimumab, and these biomarkers could potentially be predictive for its benefit.

How do these data inform us about the effects of CTLA-4 abrogation in patients? First, the pharmacodynamic effects of ipilimumab in vivo can help clarify its mechanism(s) of action. Next, some of the observed effects may be surrogate biomarkers for either toxicity or benefit, allowing an early prediction of those phenomena in patients. Some biomarkers on $\mathrm{CD}^{+} \mathrm{T}$ cells were associated with relapse in this study, and that result needs to be validated in a larger prospective study of patients with metastatic, unresectable melanoma. Our microarray data also indicated that other genes whose expression is altered in CD4 and CD8 T cells after ipilimumab might be worth exploring. Finally, some of the biomarkers that we defined herein may be predictive for the effects of ipilimumab in patients, allowing better patient selection, or may simply be prognostic for outcome independent of specific treatment. We showed that EOMES $^{+} \mathrm{CD}^{+} \mathrm{T}$ cells and $\mathrm{Ki} 67^{+} \mathrm{EOMES}^{+} \mathrm{CD} 8^{+} \mathrm{T}$ cells are biomarkers associated with clinical outcome with ipilimumab. Further studies to validate these observations prospectively may define clinically useful predictive biomarkers to select patients for ipilimumab treatment.

\section{Additional file}

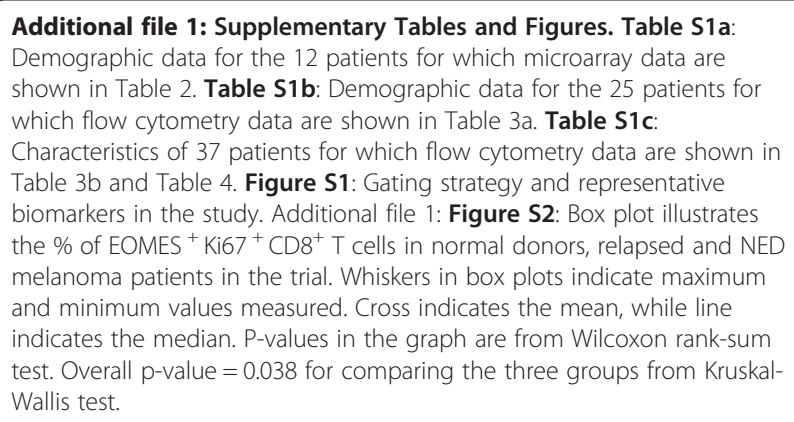

\section{Abbreviations}

CTLA-4: Cytotoxic T Lymphocyte-Associated antigen 4; PBMC: Peripheral Blood Mononuclear Cell; HS: heat inactivated human serum; TCR: T cell receptor; FoxP3: Forkhead box protein P3; EOMES: Eomesodermin; FDR: False 
discovery rate; NED: No evidence of disease; IrAEs: immune-related adverse events; RFS: relapse-free survival.

\section{Competing interest}

Dr. Weber has consulted for and accepted honoraria from Bristol Myers Squibb.

\section{Authors' contributions}

WSW conducted the microarray studies, flow cytometry studies, participated in the statistical analysis, data interpretation and drafted the manuscript. DHY supervised the statistical analysis, data interpretation and contributed to manuscript preparation. AAS collected clinic information of the patients. BY participated the microarray studies. MH participated discussion of the study. DM processed the study samples. YHZ performed the data analysis of microarray study, interpreted microarray data, and contributed to the manuscript preparation. XHZ conducted all the flow cytometry biomarkers analysis. JSW conceived the study, participated in the design and coordination, drafted the manuscript and supervised the entire study. All authors read and approved the final manuscript.

\section{Acknowledgements}

The authors would like to thank the Microarray and Flow Cytometry core personnel at the Moffitt Cancer Center for assistance with this project, particularly Steve Enkemann, Jodie Kroeger and Kate Shapland; the authors also wish to acknowledge support from the Donald A. Adam Comprehensive Melanoma Research Center and NCI R01 CA 109307. The assistance of Howard Streicher of NCl's Cancer Therapy Evaluation Program, and Rachel Humphrey as well as Axel Hoos of Bristol-Myers Squibb is gratefully acknowledged.

\section{Author details}

'Department of Cutaneous Oncology and the Donald A. Adam Comprehensive Melanoma Research Center, H. Lee Moffitt Cancer Center, Tampa, FL, USA. ²Department of Biostatistics, H. Lee Moffitt Cancer Center Tampa, FL, USA. ${ }^{3}$ Department of Bioinformatics, H. Lee Moffitt Cancer Center, Tampa, FL, USA

Received: 22 May 2012 Accepted: 22 May 2012

Published: 12 July 2012

\section{References}

1. Melero I, Hervas-Stubbs S, Glennie M, Pardoll DM, Chen L: Immunostimulatory monoclonal antibodies for cancer therapy. Nature Reviews. Cancer 2007, 7:95-106.

2. Chambers CA, Kuhns MS, Egen JG, Allison JP: CTLA-4-mediated inhibition in regulation of $T$ cell responses: mechanisms and manipulation in tumor immunotherapy. Annual Review of Immunology 2001, 19:565-594.

3. Greenwald RJ, Boussiotis VA, Lorsbach RB, Abbas AK, Sharpe AH: CTLA-4 regulates induction of anergy in vivo. Immunity 2001, 14:145-155.

4. Schneider $H$, Valk $E$, Leung $R$, Rudd CE: CTLA-4 activation of phosphatidylinositol 3-kinase (PI 3-K) and protein kinase $B$ (PKB/AKT) sustains T-cell anergy without cell death. PLoS One 2008, 3:e3842.

5. Egen JG, Allison JP: Cytotoxic T lymphocyte antigen-4 accumulation in the immunological synapse is regulated by TCR signal strength. Immunity 2002, 16:23-35.

6. Egen JG, Kuhns MS, Allison JP: CTLA-4: new insights into its biological function and use in tumor immunotherapy. Nature Immunology 2002, 3:611-618.

7. Leach DR, Krummel MF, Allison JP: Enhancement of antitumor immunity by CTLA-4 blockade. Science 1996, 271:1734-1736.

8. Quezada SA, Peggs KS, Curran MA, Allison JP: CTLA4 blockade and GM-CSF combination immunotherapy alters the intratumor balance of effector and regulatory T cells. The Journal of Clinical Investigation 2006, 116:1935-1945.

9. Chen L, Ashe S, Brady WA, Hellstrom I, Hellstrom KE, Ledbetter JA, et al: Costimulation of antitumor immunity by the B7 counterreceptor for the T lymphocyte molecules CD28 and CTLA-4. Cell 1992, 71:1093-1102.

10. van Elsas A, Hurwitz AA, Allison JP: Combination immunotherapy of B16 melanoma using anti-cytotoxic $T$ lymphocyte-associated antigen 4 (CTLA-4) and granulocyte/macrophage colony-stimulating factor (GM-CSF)-producing vaccines induces rejection of subcutaneous and metastatic tumors accompanied by autoimmune depigmentation. The Journal of Experimental Medicine 1999, 190:355-366.

11. Ueda H, Howson JM, Esposito L, Heward J, Snook H, Chamberlain G, et al: Association of the T-cell regulatory gene CTLA4 with susceptibility to autoimmune disease. Nature 2003, 423:506-511.

12. Waterhouse $P$, Penninger JM, Timms E, Wakeham A, Shahinian A, Lee KP, et al: Lymphoproliferative disorders with early lethality in mice deficient in Ctla-4. Science 1995, 270:985-988.

13. Wolchok JD, Saenger $Y$ : The mechanism of anti-CTLA-4 activity and the negative regulation of T-cell activation. The Oncologist 2008, 13(Suppl 4):2-9.

14. Maker AV, Attia P, Rosenberg SA: Analysis of the cellular mechanism of antitumor responses and autoimmunity in patients treated with CTLA-4 blockade. Journal of Immunology 2005, 175:7746-7754.

15. Ribas A: Overcoming immunologic tolerance to melanoma: targeting CTLA-4 with tremelimumab (CP-675,206). The Oncologist 2008, 13(Suppl 4):10-15.

16. Wolchok JD, Neyns B, Linette G, Negrier S, Lutzky J, Thomas L, et al: Ipilimumab monotherapy in patients with pretreated advanced melanoma: a randomised, double-blind, multicentre, phase 2 , doseranging study. The Lancet Oncology 2011, 11(2):155-164.

17. Weber J, Thompson JA, Hamid O, Minor D, Amin A, Ron I, et al: A randomized, double-blind, placebo-controlled, phase II study comparing the tolerability and efficacy of ipilimumab administered with or without prophylactic budesonide in patients with unresectable stage III or IV melanoma. Clinical Cancer Research 2009, 15:5591-5598.

18. Weber J: Ipilimumab: controversies in its development, utility and autoimmune adverse events. Cancer Immunology, Immunotherapy 2009, 58:823-830

19. Fong L, Small EJ: Anti-cytotoxic T-lymphocyte antigen-4 antibody: the first in an emerging class of immunomodulatory antibodies for cancer treatment. Journal of Clinical Oncology 2008, 26:5275-5283.

20. Phan GQ, Yang JC, Sherry RM, Hwu P, Topalian SL, Schwartzentruber DJ, et al: Cancer regression and autoimmunity induced by cytotoxic $T$ lymphocyte-associated antigen 4 blockade in patients with metastatic melanoma. Proc Natl Acad Sci USA 2003, 100:8372-8377.

21. O'Day SJ, Maio M, Chiarion-Sileni V, Gajewski TF, Pehamberger $H$, Bondarenko IN, et al: Efficacy and safety of ipilimumab monotherapy in patients with pretreated advanced melanoma: a multicenter single-arm phase II study. Annals of Oncology 2010, 21(8):1712-1717.

22. Hodi FS, O'Day SJ, McDermott DF, Weber RW, Sosman JA, Haanen JB, et al: mproved survival with ipilimumab in patients with metastatic melanoma. The New England Journal of Medicine 2010, 363:711-723.

23. Robert C, Thomas L, Bondarenko I, O'Day S, DJ M, Garbe C, et al: Ipilimumab plus dacarbazine for previously untreated metastatic melanoma. The New England Journal of Medicine 2011, 364:2517-2526.

24. Yuan J, Page DB, Ku GY, Li Y, Mu Z, Ariyan C, et al: Correlation of clinical and immunological data in a metastatic melanoma patient with heterogeneous tumor responses to ipilimumab therapy. Cancer Immunity 2010, 10:1-7.

25. Sanderson K, Scotland R, Lee P, Liu D, Groshen S, Snively J, et al: Autoimmunity in a phase I trial of a fully human anti-cytotoxic Tlymphocyte antigen-4 monoclonal antibody with multiple melanoma peptides and Montanide ISA 51 for patients with resected stages III and IV melanoma. Journal of Clinical Oncology 2005, 23:741-750.

26. Sarnaik AA, Yu B, Yu D, Morelli DR, Hall MS, Bogle D, et al: Extended dose ipilimumab with a peptide vaccine: immune correlates associated with clinical benefit in patients with resected high-risk stage IIIc/IV melanoma. Clinical Cancer Research 2011, 17(4):896-906.

27. Carthon BC, Wolchok JD, Yuan J, Kamat A, Ng Tang DS, Sun J, et al: Preoperative CTLA-4 blockade: tolerability and immune monitoring in the setting of a presurgical clinical trial. Clinical Cancer Research, 16:2861-2871.

28. Chen H, Liakou Cl, Kamat A, Pettaway C, Ward JF, Tang DN, et al: AntiCTLA-4 therapy results in higher CD4 + ICOShi T cell frequency and IFNgamma levels in both nonmalignant and malignant prostate tissues. Proc Natl Acad Sci USA 2009, 106:2729-2734.

29. Attia P, Phan GQ, Maker AV, Robinson MR, Quezado MM, Yang JC, et al: Autoimmunity correlates with tumor regression in patients with metastatic melanoma treated with anti-cytotoxic T-lymphocyte antigen4. Journal of Clinical Oncology 2005, 23:6043-6053. 
30. Ribas A, Comin-Anduix B, Economou JS, Donahue TR, de la Rocha P, Morris $L F$, et al: Intratumoral immune cell infiltrates, FoxP3, and indoleamine 2,3-dioxygenase in patients with melanoma undergoing CTLA4 blockade. Clinical Cancer Research 2009, 15:390-399.

31. von Euw E, Chodon T, Attar N, Jalil J, Koya RC, Comin-Anduix B, et al: CTLA4 blockade increases Th17 cells in patients with metastatic melanoma. Journal of Translational Medicine 2009, 7:35.

32. Comin-Anduix B, Sazegar H, Chodon T, Matsunaga D, Jalil J, von Euw E, et al: Modulation of cell signaling networks after CTLA4 blockade in patients with metastatic melanoma. PLoS One 2010, 5:e12711.

33. Ribas A, Benz MR, Allen-Auerbach MS, Radu C, Chmielowski B, Seja E, et al: Imaging of CTLA4 blockade-induced cell replication with (18)F-FLT PET in patients with advanced melanoma treated with tremelimumab. Journal of Nuclear Medicine 2010, 51:340-346.

34. Huang RR, Jalil J, Economou JS, Chmielowski B, Koya RC, Mok S, et al: CTLA4 blockade induces frequent tumor infiltration by activated lymphocytes regardless of clinical responses in humans. Clinical Cancer Research 2011, 17:4101-4109.

35. Van Gelder RN, von Zastrow ME, Yool A, Dement WC, Barchas JD, Eberwine $\mathrm{H}$ : Amplified RNA synthesized from limited quantities of heterogeneous cDNA. Proc Natl Acad Sci USA 1990, 87:1663-1667.

36. Liu WM, Mei R, Di X, Ryder TB, Hubbell E, Dee S, et al: Analysis of high density expression microarrays with signed-rank call algorithms. Bioinformatics 2002, 18:1593-1599.

37. Irizarry RA, Bolstad BM, Collin F, Cope LM, Hobbs B, Speed TP: Summaries of Affymetrix GeneChip probe level data. Nucleic Acids Research 2003, 31:e15.

38. Strimmer K: fdrtool: a versatile R package for estimating local and tail area-based false discovery rates. Bioinformatics 2008, 24:1461-1462.

39. Scholzen T, Gerdes J: The Ki-67 protein: from the known and the unknown. Journal of Cellular Physiology 2000, 182:311-322.

40. Hertoghs KM, Moerland PD, van Stijn A, Remmerswaal EB, Yong SL, van de Berg PJ, et al: Molecular profiling of cytomegalovirus-induced human CD8+ T cell differentiation. The Journal of Clinical Investigation 2010, 120:4077-4090.

41. Dong C, Juedes AE, Temann UA, Shresta S, Allison JP, Ruddle NH, et al: ICOS co-stimulatory receptor is essential for T-cell activation and function. Nature 2001, 409:97-101.

42. McAdam AJ, Chang TT, Lumelsky AE, Greenfield EA, Boussiotis VA, DukeCohan JS, et al: Mouse inducible costimulatory molecule (ICOS) expression is enhanced by CD28 costimulation and regulates differentiation of CD4+ T cells. J Immunol 2000, 165:5035-5040.

43. Pearce EL, Mullen AC, Martins GA, Krawczyk CM, Hutchins AS, Zediak VP, et al: Control of effector CD8+ T cell function by the transcription factor Eomesodermin. Science 2003, 302:1041-1043.

44. Bauquet AT, Jin H, Paterson AM, Mitsdoerffer M, Ho IC, Sharpe AH, et al: The costimulatory molecule ICOS regulates the expression of c-Maf and IL-21 in the development of follicular T helper cells and TH-17 cells. Nature Immunology 2009, 10:167-175.

45. Fu T, He Q, Sharma P: The ICOS/ICOSL Pathway Is Required for Optimal Antitumor Responses Mediated by Anti-CTLA-4 Therapy. Cancer Research 2011, 71:5445-5454.

46. Ribas A, Comin-Anduix B, Chmielowski B, Jalil J, de la Rocha P, McCannel TA, et al: Dendritic cell vaccination combined with CTLA4 blockade in patients with metastatic melanoma. Clinical Cancer Research 2009, 15:6267-6276.

47. Critchley-Thorne RJ, Yan N, Nacu S, Weber J, Holmes SP, Lee PP: Downregulation of the interferon signaling pathway in $T$ lymphocytes from patients with metastatic melanoma. PLoS Med 2007, 4:e176.

48. Rudd CE: CTLA-4 co-receptor impacts on the function of Treg and CD8+ T-cell subsets. Eur J Immunol 2009, 39:687-690.

\section{doi:10.1186/1479-5876-10-146}

Cite this article as: Wang et al:: Biomarkers on melanoma patient T Cells associated with ipilimumab treatment. Journal of Translational Medicine 2012 10:146.

\section{Submit your next manuscript to BioMed Central and take full advantage of:}

- Convenient online submission

- Thorough peer review

- No space constraints or color figure charges

- Immediate publication on acceptance

- Inclusion in PubMed, CAS, Scopus and Google Scholar

- Research which is freely available for redistribution 